\title{
Co-Financing of Bottom-Up Approaches towards Broadband Infrastructure Development: A New Opportunity for Universal Service Funding
}

\author{
Idongesit Williams
}

CMI, Aalborg University

E-mail:idong@cmi.aau.dk

Received 16 June 2015;

Accepted 21 February 2016

\begin{abstract}
Bottom - up Broadband infrastructure development facilitated by the civil societies and social enterprises are on the increase. However, the problem plaguing the development of these bottom-up approaches in developing countries is the financial capacity to expand their small networks into larger networks - leading to the demise of some of these initiatives. This paper proposes co-financing of these networks as a means of sustaining the bottomup Broadband network. The argument of this paper is anchored on two of developing country cases. One in India and the other in Ghana. One survived with financial injection and the other did not due to low revenue. This paper, based on these cases, proposes the utilization and the reintroduction of Universal Service funds in developing countries to aid these small networks. This is a qualitative study, the Grounded Theory approach was used adopted gather data for these cases.
\end{abstract}

Keywords: Universal Access and Service, Broadband Infrastructure, Universal Service funds.

Journal of NBICT, Vol. 1, 39-64.

doi: 10.13052/NBICT.2016.003

(c) 2016 River Publishers. All rights reserved. 


\section{Introduction}

This paper makes an argument for the utilization of Universal Service funding to fund community based bottom-up Broadband infrastructure in developing countries. This argument became necessary as a result of the ever growing interest in some rural communities in developing countries towards facilitating their own wireless Broadband infrastructure. The problem that such communities face, though, is the lack of financial capacity to facilitate the Broadband infrastructure. Hence some of these initiatives - especially in sub-Saharan Africa - do not survive. A few of such initiatives in developing and developed countries do evolve to become big Broadband coops, social enterprises and even Internet Service Providers to rural areas. The difference between the rural Broadband bottom-up initiatives that survived and those that do not survive was the availability of financial resources. Hence, this paper explores the possibility of adopting Universal Service funds as a means of co-financing such projects. This will lead to the extension of low-cost Broadband infrastructure in rural areas of developing countries-leading to the possibility of Universal Access and Service of Broadband infrastructure in certain countries.

This line of argument is inspired by certain findings in an ongoing research at CMI, Aalborg University. In this research, six bottom-up initiatives from different continents - in most parts of the globe- were examined. Three of the cases were developed country cases, and three of the other cases were developing country cases (Williams, 2015). The developing countries' cases of interest were located in Ghana, India and South Africa. The aim of the ongoing research was to understand the factors that enabled these civil society groups facilitate Broadband infrastructure development. The inspired finding, among other findings, that is of interest to this paper is that almost all the cases either had to seek external funding sources or generate funding internally in order to design build operate and maintain the wireless and fixed Broadband networks. Successful bottom-up initiatives had a successful investment to revenue flow, while the unsuccessful ones, had a truncated investment to revenue flow at some point. Hence, this strengthened the call for co-financing possibilities for such projects, especially in developing countries (Hudson, 2014).

The proposition for adopting Universal Service funding is based on the fact that most Universal Service funds sit on unused funds that would help selected rural areas develop low-cost Broadband Internet infrastructure (See

(GSMA, 2013)). As rural areas are not known to be commercially viable to attract Private Broadband infrastructure investment (see (Calandro \& Moyo, 2010)). This unused funds can be used to support community Broadband 
initiatives. The initiatives are bottom-up approaches, as it is the people and civil societies facilitating the development of Broadband networks. This effort would supplement the market driven effort in facilitating Broadband infrastructure in different developing countries and sub-Saharan Africa countries. The advantage of people led initiatives is that small, localized Broadband networks can be developed and owned by the people (Yardley, 2012). This will provide rural areas with access to cost effective wireless Broadband infrastructure.

In this paper, the individual cases identified in India and Ghana are the source of the major empirical findings discussed in this paper. The first case is that of the Dharamsala Wireless network in India. The second case is that of the Ghana Wireless Project. The Indian case is one where some form of external funding led to its sustenance. The Ghanaian case is one case where the lack of funding led to the development of a small network, which could not be sustained economically. The study is qualitative in nature and the Grounded Theory was used to analyze the cases. The rationale for choosing these cases is because they are developing country oriented cases. One is a case of Africa, the second is a case of India. Thirdly, these initiatives occurred in rural areas.

To supplement the argument based on the cases, the finding is supplemented by literature review on bottom-up initiatives, Universal Service funding and the opportunities for funding bottom-up initiatives using the Universal Service funding in developing countries. Although this paper has an overall implication on developing countries, its major target is sub-Saharan Africa.

\section{The Rationale for Universal Service Funding for Bottom-Up Initiatives in India and Ghana}

Though these initiatives exist in these case studies, Ghana and India are countries that need more bottom-up initiatives. Both countries also fund the facilitation of telecommunication networks in underserved areas using Universal Service funds ((GIFEC, 2012) (USOF, 2002)). However, both countries are yet to fund community Broadband networks. In India, there is the possibility to fund community Broadband networks using Universal Service funds. However, such groups will have to compete with Network Operators and Internet Service Providers for such funds. Hence, these networks do not have the chance of winning the minimum subsidy bid (See (Noll \& Wallstein, 2005)). In Ghana, the possibility to fund these initiatives exist and 
the Universal Service fund is open to funding such initiatives, but communities are not aware that they can approach the Universal Service funds to fund their initiatives (Williams, 2015).

These countries need Broadband infrastructure in their rural areas. Fixed Broadband penetration is $1.2 \%$ and $0.3 \%$, while mobile Broadband penetration is 5.5\% and 59.8\% in India and Ghana respectively (Broadband Commission, 2015). However, there is no guarantee that the market will be able to deliver Universal service of Broadband infrastructure and service. In India, rural mobile teledensity in 2015 was $47.78 \%$ (TRAI, 2015). Though the purchasing power of the Indian rural dwellers has increased over the years, $43 \%$ of rural India still basic infrastructure, such as electricity (Swati \& Pratrap, 2015). Hence there is the need for an innovative way of facilitating Universal Service. This is because there is no guarantee that the market will facilitate Broadband connectivity in rural areas with little or no basic amenity. The case presented in this paper, points to the fact that people in rural India can be mobilized to facilitate community Broadband Networks. However, Universal Service funding will be needed to aid such an initiative, as people groups may lack the resources to facilitate such a network.

Similarly, in Ghana, $50.9 \%$ of the citizens live in urban areas (Ghana Statistical Service, 2012). Based on this report, Greater Accra and Ashanti region account for a large population of rural dwellers. Other regional capitals and smaller districts account for a smaller population of urban dwellers. This implies that $49.1 \%$ of the citizens live in rural areas. Based on the aforementioned quote from the Broadband Commission, mobile Broadband infrastructure delivering $3 \mathrm{G}$ services is present in $8.9 \%$ of rural Ghana. However, in December, 2015, MTN (One of the 6 mobile network operators in Ghana) was allocated the $4 \mathrm{G}$ spectrum via an auction (Dowuona, 2015). This will force other market competitors to reduce their effort in providing $3 \mathrm{G}$ in rural areas to improve the Quality of Service of their services in the city. Hence the Universal Service of mobile Broadband in Ghana may likely stall. Hence, it is imperative that a new approach is adopted towards facilitating Broadband Infrastructure in rural Ghana. The case presented in this paper indicates that rural Ghanaians, if supported financially can facilitate a cost effective wireless network. There is a need for more of such initiatives. However, based on the socioeconomic conditions of the people living in rural Ghana, Universal service funding will come in handy.

In both countries, the gateway opportunity exists. Both countries have embarked on extensive National fibre Optic networks that run through rural areas. Hence connectivity is not far from them. As will be discussed in 
this paper, the communities seem to go for Broadband solutions that are cost effective. However, as these communities are sometimes financially handicapped, they are unable to sustain the infrastructure. The Universal Service funding will come in handy to support their initial capital expenditure. Research as shown that people groups are able to sustain the Broadband networks, if their initial operational expenditure is taken are of (Williams, 2015).

\section{A Brief Overview of Community based Bottom-Up Initiatives}

On every continent around the globe, one can identify a minimum of 5 community wireless Broadband networks. Five is mentioned here because there is an uneven distribution of community Broadband networks globally. A search carried out to document the density of Broadband networks globally, indicated that rural community Broadband networks are rare in sub-Saharan ((Williams, 2015)). However, these networks exist in large numbers in North America and in the EU (See (Oost, Verhaegh, \& Oudshoorn, 2007) (Williams, 2015) (Salemink \& Bosworth, 2014)). A sizable number of these networks can be sighted in Asia and South America (see (Finquelievich \& Kisilevsky, 2005)). Although the aforementioned uneven distribution exists, at least 5 of such networks can be sighted in each continent. An attempt to search for some wireless networks from each continent produced the identified networks in the Table 1.

These are regions and countries with strong utility coop traditions (Viardot, 2013; Finquelievich \& Kisilevsky, 2005). These coop traditions dates back to civil society efforts to revitalize utilities that had collapsed as a result of the great depression (Viardot, 2013). Hence the telephone co-op tradition has metamorphosed into Broadband coops.

These Broadband networks are facilitated as a result of people led initiatives (Salemink \& Bosworth, 2014). Hence, they are bottom-up initiatives. However, in recent times, these bottom-up initiatives have been supported by the municipality or the central government (Salemink \& Bosworth, 2014) (Tapia, Maitland, \& Stone, 2006). These are hybrid forms of developing Broadband infrastructure (Salemink \& Bosworth, 2014). In such cases, the municipality or the central government fully or partially fund Broadband infrastructure development. The municipality, in conjunction with the coops hand design, build and in some cases maintain infrastructure and co-finance 
44 I. Williams

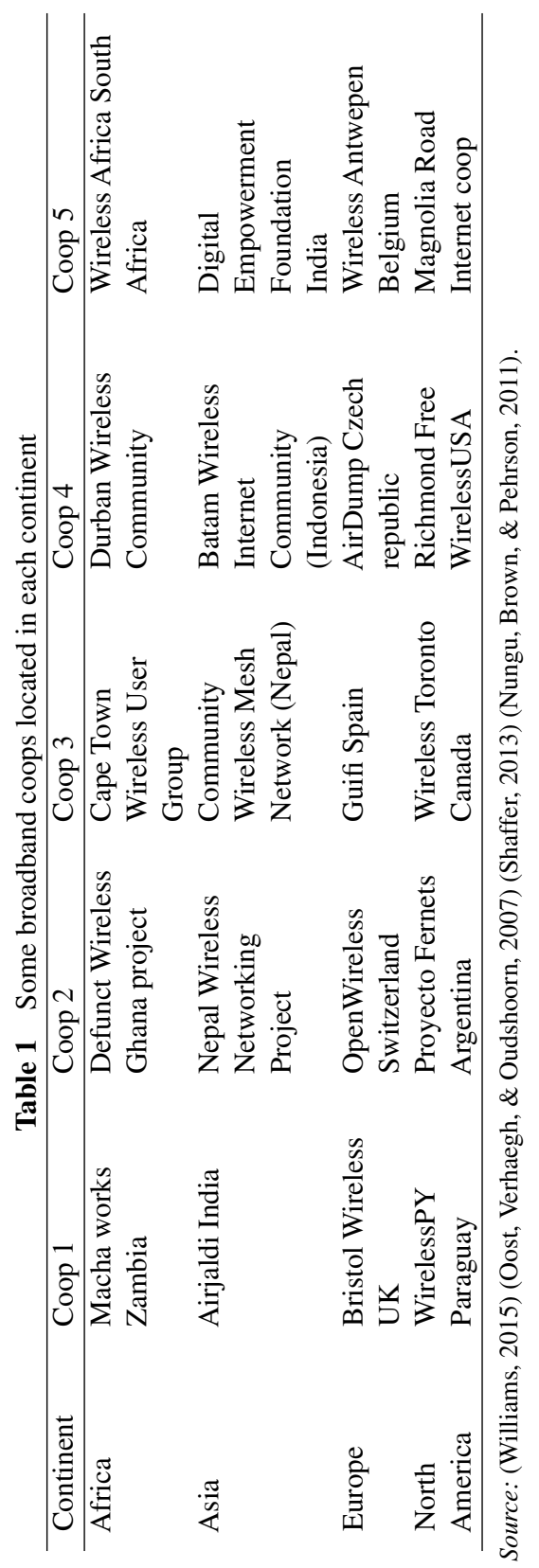


the infrastructure. Such initiatives are prevalent in Sweden, UK and US (Salemink \& Bosworth, 2014) (Lindskog \& Johansson, 2005) (Strover \& Mun, 2006). This could occur the form of a Public Private Partnership as in the case of the Almhult Municipality Broadband initiative (Williams, 2015). The public sector interest in most cases is to facilitate e-government services as well as facilitate social inclusion of the citizens. These public initiatives are often identified in National Broadband Policies. The interest of the community has been to facilitate social inclusion as well as gain access to ICTs for various purposes.

In Africa, wireless Broadband networks are rare. But most visible community wireless networks are concentrated in the Republic of South Africa.

In African countries, these bottom-up initiatives occur without any form of direct public funding. The cases identified in South Africa began mostly as neighborhood networks that grew to become city and town wireless networks. These networks were developed at the time access to mobile and Broadband networks were expensive (Williams, 2015). However, these networks do not serve parts of the rural South African population. This calls for discussion on how more community networks can be funded in rural areas in South Africa and sub-Saharan Africa at large.

The similarity between the rest of the world and Africa is the potential for organizing small rural communities via coops. Co-ops exist in Africa. However, they are not necessarily utility co-ops, but rather coops aimed at economic empowerment (Tesfamariam, 2015). But a few, utility coops do exist (see (Henry \& Constanze, 2011). The existence of these coops serves as an opportunity to organize rural people to facilitate low cost-Broadband infrastructure such as Wi-Fi.

The reality, though, is that, these community wireless networks - both in Africa and in other areas around the globe - has led to the provision of wireless Broadband connectivity in areas where Broadband connectivity was poor or non-existent.

\section{Overview on the Adoption of Universal Service Funding}

One of the revolutions that came with the telecom market reforms was the introduction of universal service funding agencies or Universal Service fund agency (Calandro \& Moyo, 2010). By setting up these Universal Service funds, an avenue for direct public financing of telecommunication infrastructure was created to cater for telecom infrastructure deficiency in areas where the market could not cater for. The funds are administered mostly via the provision of 
subsidies by the funding agency to the incumbent network operators to aid them facilitate telecom infrastructure in rural areas (Blackman \& Srivastava, 2011). In recent times, this involves, the development of public infrastructure by the funds for the usage of the incumbent operators. However, the operations of Universal Service funds and their approach towards serving the underserved communities vary slightly from country to country.

The jurisdiction of the agency is mostly rural areas or areas that are not commercially viable. The funding agencies were funded mostly from a certain percentage of annual or quarterly proceeds from the existing network operators depending on the nation involved as seen in Table 2 and in Figure 1 below.

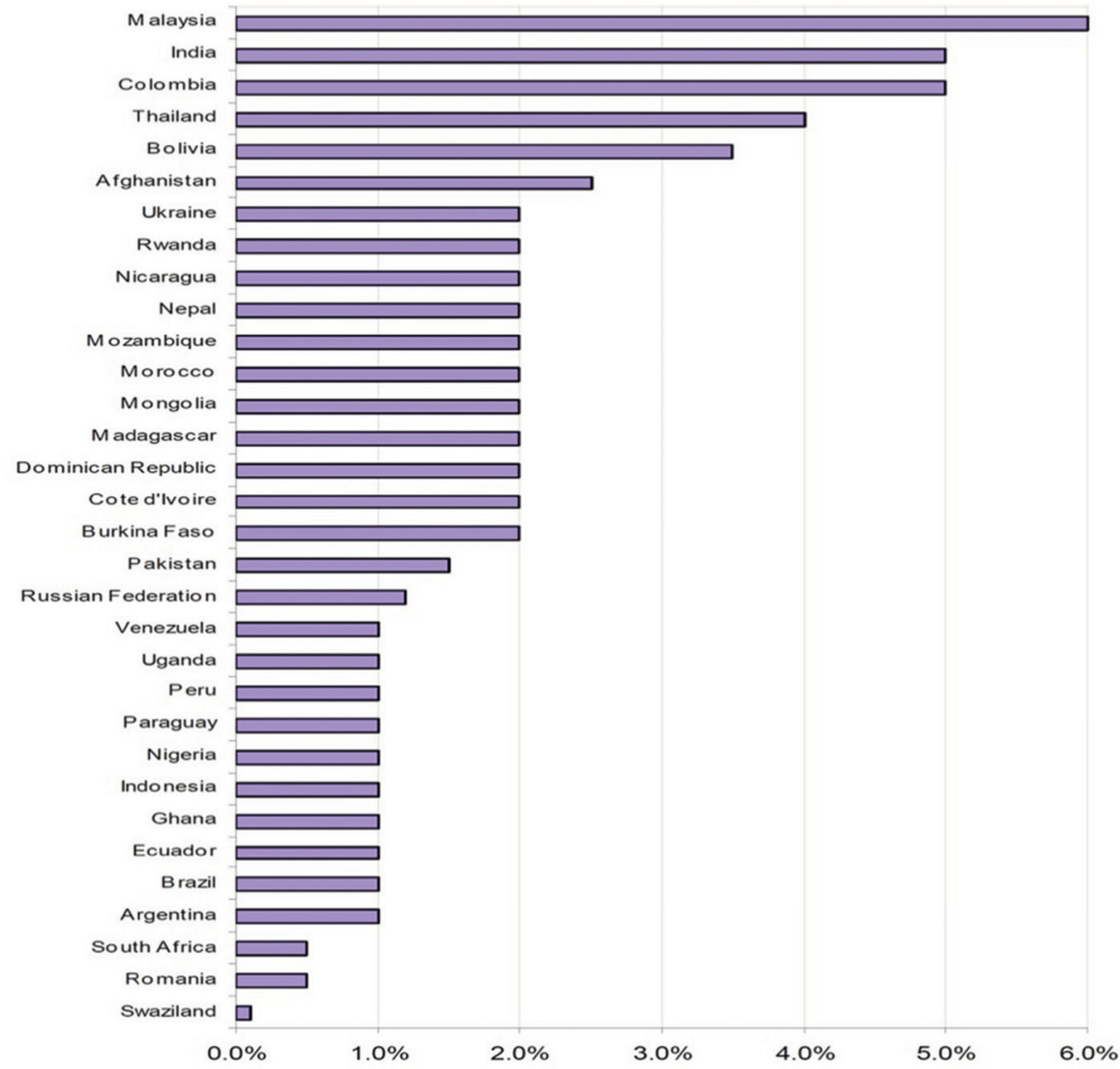

Figure 1 Private sector contribution to Universal Service Funds from selected countries source (GSMA, 2013). 


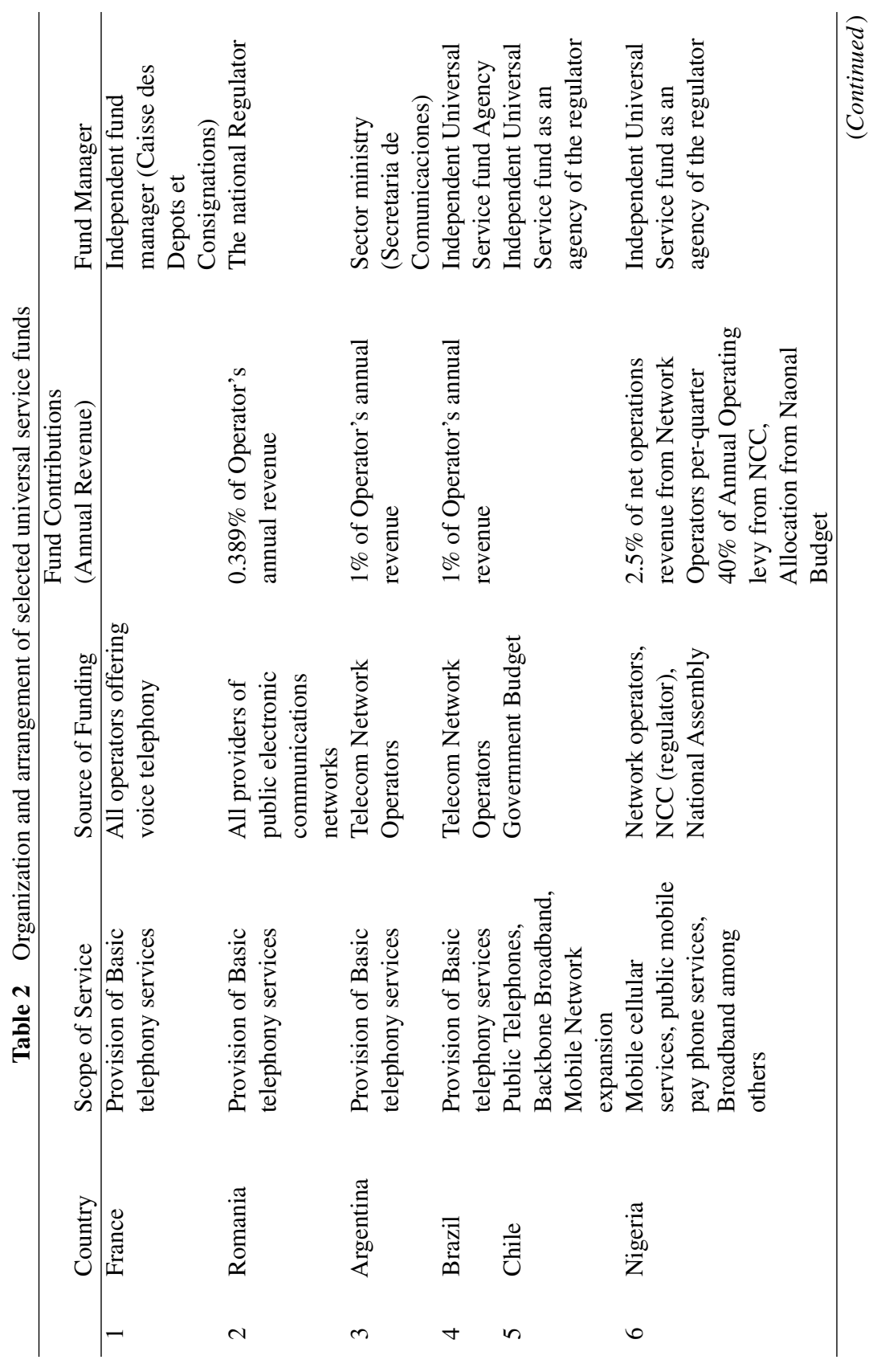


$48 \quad$ I. Williams

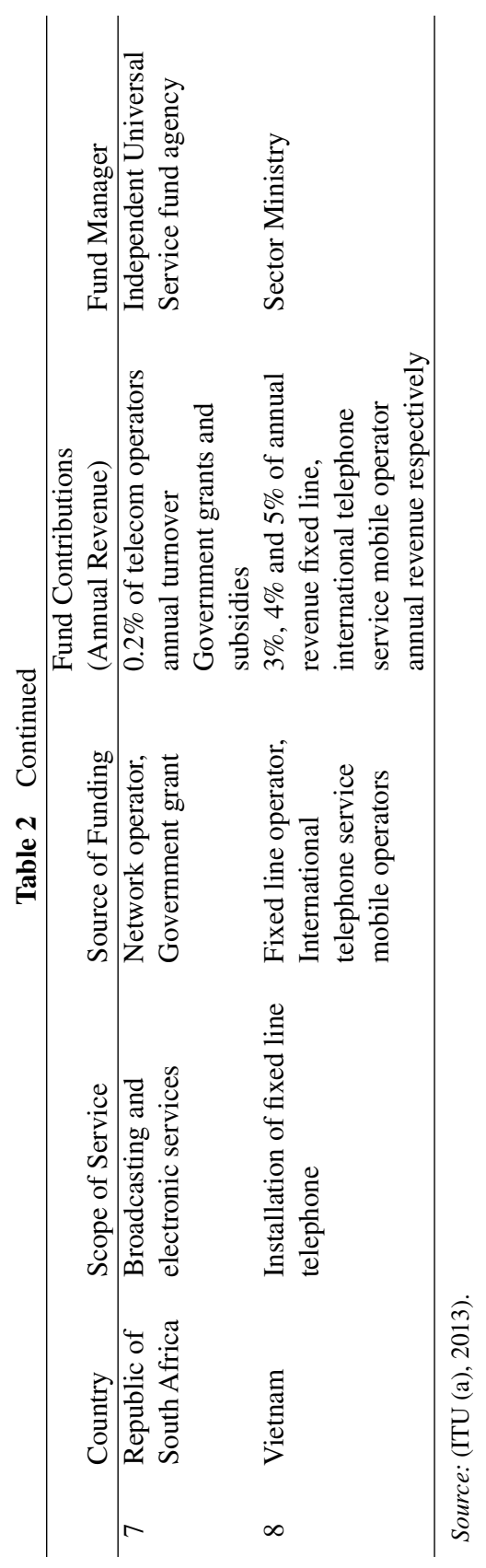


In countries like Nigeria, part of the funding emanates from the national budget. Examples of funding mechanisms identified from few selected countries are expressed in the Table 2. However the operations and management of the funds is often stipulated by the law of the respective countries. The law creates a boundary of where, why, how and whom the Universal finds should fund. As a result of the diverse legal frameworks, some Universal Service funds are either an independent public agency operating under a sector ministry or either an arm of the national regulator or the fund is actually controlled by the regulator. Examples of Universal Service funds and how they are organized can be seen in the Table 2 .

Although these organizational and financial arrangements exist, it is not every country that has a universal service fund. Countries like UK, Germany, Norway, Ireland, The Netherlands and Denmark do not have Universal Service funds. This does not imply that they do not have alternative funding mechanisms for public funding of Universal Service.

In the UK, Universal Service Obligation (USO) is used to fund Universal Service. The USO involves the incumbents, British Telecoms and Kingston communications (Hull), funding the cost of network expansion from profits made on higher margin service (OFCOM, 2005). Under this condition, these companies were to provide a special tariff scheme to low earning customers, connectivity to a fixed network, that will also provide Internet access; reasonable geographical reach to public call boxes and appropriate service for disabled customers (UK Universal Service Obligation, 2005). It is important to note that there is a proposal for the establishment of a Universal Service fund in the UK. The reason for the proposal is to lift the USO from the incumbents, whose profit margins could be eroded as a result of the emerging competition. The effect of the eroding profit margins could make the USO a burden on the incumbent (OFCOM, 2005).

As mentioned earlier, Germany, Norway, Ireland, Denmark and the Netherlands are some countries without a Universal Service fund or a current Universal Service Obligation for Broadband (OECD, 2012). National Broadband plans in these countries are facilitated by public incentives aimed at facilitating market based competition and technology neutrality (EC, 2014) (OECD, 2012). Some of these countries, such Germany do have laws that enacted the Universal service fund, but it has not been implemented (Köthenbürger, Sinn, \& Whalley, 2006). The approach adopted by these countries have been buttressed by the fact that Universal Service funds are not needed as the market can facilitate Universal Access and Service (OECD, 2012). 
In countries that have implemented Universal Service funds agencies, not all of them are active. In a 2013 study done by ITU on 66 Universal Service funds located in various regions of the world, Africa and Asia had a higher number of inactive Universal Service funds (ITU (a), 2013). The identified inactive funding agencies in Africa were inactive, either as a result of the fact that the network operators refused to contribute to the funds or because they had contributed to the funds but there was no clear guideline on how the fund will be disbursed. In Asia, the funds that were active, were either not operational at the time the ITU report was produced or the operations of the funds had been suspended. Although, in some of the countries, the level of activity was low, the network operators were paying the levies. The inactivity of the Universal Service fund and the halting of operations brings up issues of the transparency in the management of the funds by the identified Universal Service funds. It also raises issues of the Universal Service funds, probably lacking ideas on how to invest the funds. However, in these continents, there were funds that were identified high activity levels. In Africa, Nigeria, Uganda, Sudan and Ghana were identified as funds with high activity level (See (ITU (a), 2013)). In Asia, Afghanistan, India, Indonesia, Malaysia, Pakistan and Thailand were identified as owning Universal Service funds with high activity level (See (ITU (a), 2013)). This indicates that the lack of transparency of the Universal Service funding is not endemic in these continents. However, the countries with high activity, do not lack ideas, they are open to innovative ways of funding their mandate. Hence, they invest in their mandate by facilitating capacity building initiatives as well as funding rural telecom infrastructure delivery (ITU (a), 2013). In Ghana and Nigeria, as examples, the Universal Service funds also accept ideas on innovative rural telecom infrastructure schemes from citizens (Williams, 2015). Schemes that are feasible are implemented. This contributes to high level activities as well. The openness to external ideas towards facilitating rural Broadband infrastructure by some Universal Service funds inspires the writing of this paper as well.

However, the level of inactivity or low activity of some Universal Service funds has not gone unnoticed by mobile network operators who contribute more to the telecoms market in these countries. They view their contribution to Universal Service funds as a burden (GSMA (a), 2013). As a result of the low level of activity and the inactivity of some funding agencies, the GSM association estimated that US\$ 4.4 billion dollars of Universal Service funds globally, was unspent (GSMA, 2012). However, the GSMA, also attributed the surplus to the lack of ideas on what to use the funds for, even in countries 
with high activity. The association estimated an extra US\$ 3.8 Billion dollars to be accrued by Universal Service funds by 2020 . The association envisages that the amount of unspent reserves with Universal Service funds would have been more productive for network expansion by mobile network operators. Although this is a valid argument, this paper argues that the unspent reserves can be used to facilitate low-cost Broadband infrastructure delivery in rural areas.

The difference in opinion is not to dispute the GSMA, but to argue that some Universal Service funds in Africa do not to utilize the Universal Service funds because they believe the market will facilitate mobile connectivity (Williams \& Kwofie, 2014). This is because the facilitation of telecommunication infrastructure since the dawn of market liberalization in Africa has been based on facilitating competitive markets (Williams \& Kwofie, 2014). In developing countries where there is high activity by the Universal Service funds, aside Broadband infrastructure delivery, most of the resources are spent on facilitating demand for the services that will be provided ultimately by the private sector (See (ITU (a), 2013)). Hence, network infrastructure delivery requires a more concerted effort. The emergence and the willingness of rural dwellers in developing countries to facilitate Broadband networks produces an important player in the market- the people. This player cannot be neglected, but rather strengthened to facilitate national Broadband Universal Access and Service policy objectives. Hence, co-financing their efforts with Universal Service funding is a great deal of encouragement to this new player in the market.

The vital question now remains, what opportunities exist that would warrant spending Universal Service funds?

\section{The Opportunity for Bottom Up Initiatives in Developing Countries}

There are lots of opportunities that exist for funding community Broadband initiatives in Africa and developing countries. However, in this paper, the focus will be on 3 of these opportunities. These opportunities are:

1. The opportunity of financing the network: This is the crux of the paper. As mentioned earlier, there is the possibility of co-financing by Universal Service funding. This could be via a Public Private People Partnership or the direct funding of coops of rural village councils. In this paper the direct training and funding of coops or rural village councils. 
2. Existing gateway connectivity: In developing countries, especially in sub-Saharan Africa, there is an extensive development of backhaul fiber optic networks. Some of these networks pass through rural areas ad two major cities are connected. In Africa, Broadband Internet connectivity exists in a few rural areas via the delivery of $3 \mathrm{G}$ mobile networks. Some of these Mobile networks, provide mobile Internet services as well. These possibilities present a gateway for providing Broadband Internet to lowcost Wi-Fi networks in small localized rural areas. The bottleneck here would be the regulation of interconnection between the rural Broadband access network and the backbone they are connected to.

3. Possibility for community organization: The existing social structures, that can aid community organization. In countries with no local governance structures, local neighborhood co-ops can be formed to develop low cost wireless Broadband infrastructure in their areas. As mentioned, earlier, the formation of coops is not new to African rural communities. What would be necessary to establish is the usefulness of the service, to the rural dweller.

The existence of a possible gateway and the potential for community organization, though great opportunities are not strong enough grounds to get the community together to facilitate the infrastructure. Hence there will be this question of how do we pay for it? This question is buttressed from 2 cases. One in Ghana and the other in India, both developing countries. In both cases, two NGO's embarked on the facilitation of Wi-Fi enabled Broadband networks. Both had the will and limited capacity to facilitate the network. The Indian case was sustained, while the Ghanaian case got stuck. Their cases are presented below.

\section{The Cases}

In describing each case, the Universal Service regulatory environment is explained before the description of the cases. This approach provides a regulatory environment, these cases operated under.

\subsection{Regulatory Framework of India and Ghana}

\subsubsection{Overview of regulatory framework in India}

Telecom regulation in India is managed by different agencies under the ministry of Communications and Information Technology. The ministry oversees five different agencies as seen in the Table 3. 
Table 3 Some Indian regulatory agencies and their responsibilities

\begin{tabular}{lll}
\hline & Agency & Responsibilities \\
\hline 1 & $\begin{array}{l}\text { The Telecommunication } \\
\text { Commission }\end{array}$ & $\begin{array}{l}\text { The inter-ministerial body in charge of } \\
\text { policy making licensing and coordination } \\
\text { matters }\end{array}$ \\
2 & $\begin{array}{l}\text { Department of Telecommuntion } \\
\text { Telecom Regulatory Authority of } \\
\text { India }\end{array}$ & $\begin{array}{l}\text { Licensing } \\
\text { Facilitate a competitive market and play } \\
\text { the role of an arbitrator for telecom license } \\
\text { holders } \\
\text { Development of standards an equipment } \\
4\end{array}$ \\
$\begin{array}{l}\text { Telecommunications } \\
\text { Engineering Centre } \\
\text { Wireless planning and }\end{array}$ & $\begin{array}{l}\text { approval } \\
\text { Spectrum management and coordination }\end{array}$ \\
& coordination & \\
\hline
\end{tabular}

Sources: (Units under DOT, 2015) (TRAI, 2000) (Noll \& Wallstein, 2005).

The, Wireless Planning and Coordination agency and the telecommunications engineering center are also agencies of the Department of Telecommunications (DOT) ((Units under DOT, 2015)). One would say that the existence of multiple agencies here would naturally result in:

1. A high administrative cost for the sectoral ministry and the department of telecommunications.

2. The existence of bureaucracy, as a new entrant in the market would have to gain approval from different agencies before commencing business.

The level of bureaucracy and administrative cost could be reduced if a single agency were in charge of the different facets of regulating telecommunication services in India. However, the potential of serving a huge market outweighs the market entry challenges. As a result of this, the telecommunication sector in India is growing at a positive rate of $45 \%$ annually (Srivastava, 2012).

Although these 5 agencies - among others - exist, India's approach towards facilitating Universal Service has been via Access Defiecit charges (defunct), Universal Service Obligations, the utilization of Universal Service fundings via subsidy auctions and the facilitation of a competitive market (see (USOF, 2002) (Jain \& Sridhar, 2003)).

Universal Service Obligations were granted to incumbent telecom operators (Basic Telecom Operators) when granted operational licenses by the Department of Telecommunications (Jain \& Sridhar, 2003). The Universal Service Obligation Fund of India is an agency under the Department of Telecommunications charged with facilitating rural connectivity (USOF, 2002). They are funded by $5 \%$ of the annual gross revenue accrued from telecom Service providers. Funding is carried out the award of the subsidy 
via reverse auction. However, every carrier is not eligible to participate in the reverse subsidy auction process. The Indian Telegraph Amendment Act of 2004, identifies, "Basic Service Operators, Mobile Cellular Service Providers and Unified Access Services Licensee or any other entities as may be specified by the central government" (ref (DOT, 2004)). However, based on this quotation, it is clear at the Government of India is open to co-opting more telecommunication service carriers as subsidy beneficiaries. Basic Service in voice calls delivered either by a copper-based local loop connected to the Public Switched Telephone networks (PSTNs) or Wireless Local Loops (WLL) (Jain \& Sridhar, 2003). The facilitation of a market based competition is the prerogative of the Telecom Regulatory Authority of India (TRAI). TRAI regulates tariffs, telecommunication services and facilitates a fair and transparent environment for the market players.

What is missing in the Indian telecommunication framework and in their approach towards facilitating Universal Access and service is the effort at funding community based bottom-up initiatives. However, in India, bottomup initiatives exist. These include the Dharamsala Wireless network mentioned in this paper. However, these bottom initiatives are unable to gain the Basic Service licences, hence they apply for Internet Service Provider licenses (Siochrú \& Girard, 2005). As a result of this fact, these small community Based networks are not eligible to contest for the Universal Service Obligation Fund subsidy. Facilitating these bottom-up networks would be a plus to India.

\subsubsection{Overview of regulatory framework in Ghana}

Telecom regulation in Ghana is practically handled by the national independent regulator, The National Communications Authority (NCA). Unlike the case of India, one agency regulates every aspect of the telecommunications industry in Ghana. Before the establishment of the NCA, the telecommunications industry was regulated by the sectoral ministry (Williams \& Kwofie, 2014). Universal Access and Service in Ghana was facilitated via Universal Service Obligations, Universal Access funding and via the facilitation of a market based telecommunications market. The NCA facilitates market based competition as well as grants Universal Service Obligation to incumbent operators. While the Universal Service fund, Ghana Investment Fund for Electronic Communications (GIFEC), facilitate rural connectivity to rural areas and underserved areas in Ghana (GIFEC, 2012). To carry out its duties, GIFEC is funded by $1 \%$ annual contribution from the profit of telecommunication operators. GIFEC funds rural projects initiated by either GIFEC, Non-Governmental Organizations (NGOs), communities or by individuals with ideas on how to 
facilitate rural connectivity. GIFEC has this leeway of operations because the Electronic Communications Act of 2008, which grants GIFEC its legal backing to operate, does not streamline whom GIFEC should fund. The act does not also delimit GIFEC from funding any telecommunications service - hence the act encourages technology neutrality. This gives GIFEC the opportunity to fund projects that fit into its mandate by their prerogative.

However, looking through the list of projects handled by GIFEC, they are yet to fund bottom up community based Broadband networks.

\subsection{Brief Description of the Cases}

\subsubsection{Dharamsala wireless network India}

Dharamsala is located in the district of Kangra, in the state of Himachal Pradesh. Dharamsala is the home of the Tibetan Government in exile. It is made up of the urban tourism areas and the rural areas scattered over the mountainous areas. It is home to 136536 people. The literacy rate is $85.85 \%$. The majority of the citizens are farmers, others are citizens are public servants, skilled workers, artisans and a sizable number are unemployed. (See source (Census Info India, 2011)).

In 1998, Yahel Ben David was invited to India to facilitate a wireless network using his NGO. He used his financial resources and previous knowledge about wireless networks to facilitate a Wi-Fi wireless network connection in Dharamsala. He and a group of volunteers handled this project for almost 10 years till after Wi-Fi spectrum was deregulated in 2005. This was a small network serving the tourist that visit Dharamsala as well as NGOs, schools and few other organizations. The factors that led to the development of the network was the presence of demand for the Service. Prior to the building of the network, NGOs in Dharamsala had to access information to and fro the outside world from a single NGO with VSAT connectivity. Here, emails would be printed on floppy discs and transported by motorcyclists between the NGO with connectivity and the NGO that needs the information. Yahel saw the usefulness of VSAT technology as a means of redistribution the bandwidth to the other NGOs remotely Wi-Fi. Finally, Yahel had the necessary human, financial and social resources needed to facilitate connectivity. To reduce the cost of deployment, solar energy is harnessed a source of energy for the base stations, while hill tops are used to mount towers.

In 2005, investors led by Jim Forster, saw the commercial usefulness of the technology and decided to invest in the network. In the interview with Jim, he pointed out that they did not go for Universal Service funds because 
the company was not big enough to attract the funding. In India as mentioned earlier, Universal Service fundings are awarded via subsidy auctions to the lowest bidder (Noll \& Wallstein, 2005). However, if there was a promotion policy aimed at promoting bottom-up approaches, more of such initiatives would have been developed.

\subsubsection{Overview of the Ghana Wireless project}

Apredie is a small town in the Akuapem North District, in the Eastern region in Ghana. Most of the inhabitants of this area are farmers. In 2005, the Apredie Community Centre, an NGO owned by CBlit (with offices in Ghana and the USA) facilitated a Wireless Broadband network. They redistributed a $1 \mathrm{MB}$ bandwidth to 20 subscribers in the area. The inspiration came from a peace corps member from the United States, named John Atkinson. He had to convince the NGO admin about the feasibility of the network by practical demonstrations. It was his demonstrations that revealed the fact that the NGO had the resources to deploy the network. He was also able to harness the interest of few local users to adopt the network. However, this network did not last due to the inability to attain financial equilibrium, as the revenue was less than investment. The need for bandwidth increased, but the users were not willing to pay more for the service due to poor quality of service. Hence it was difficult to upgrade the network. At this point the NGO decided to discontinue the service. The village council were willing to take over the management of the network. However, the village council and the NGO could not come to terms with respect to the equipment. The network was replaced by a commercial Internet Service provider TeledataICT.

\subsubsection{Similarities between the cases}

1. Both cases were bottom-up initiatives

2. Both cases were facilitated by NGOs

3. Both cases were initially facilitated by individual enthusiasts

4. Both cases were funded by the NGO initiatives

5. Both cases were small, localized networks

6. Both countries have Universal Service funds

7. Both had no public funding

\subsubsection{Differences between the cases}

1. The Indian case was sustained by commercial funding, while the Ghanaian case did not have an external funding source. 
2. In the Indian case, the people saw the need for the service from the onset, while in the Ghanaian case, the people saw the need as they saw how useful it was to their neighbors.

3. The Indian case was born out of a demand pull, while the Ghanaian case was born out of a supply push by the NGO.

Although both cases are not similar, both of them were small networks when they had to transit into becoming bigger commercial networks. In the case of Dharamsala, the transition came before there could be a financial disequilibrium. In the case of the Ghana Wireless Project, the transition was their breaking point as quality of service became a problem as they took on more subscribers sharing limited bandwidth. The challenge that both cases had to overcome was not the facilitation of the network, rather it was in the maintenance of the networks. In order to maintain the network they had to maintain the Quality of Service, avoid financial risk via financial disequilibrium, and also expand the network as a means of building a potential economy to sustain the network. In these three areas, Universal Service funds have the potential of mitigating one or all of these areas depending on the circumstances.

1. Maintaining Quality of Service: If both NGOs had funding from the Universal Service funds, part of the money they would have raised from the people and from other sources would have led to the facilitation of greater bandwidth. In the case of the Wireless Ghana Project, the funds would have led to the extension of connectivity to more users. This is because more users would have been impressed with the quality of service of the network and sign up for it.

2. Avoiding financial disequilibrium: The challenge for people living in rural communities is that they may not necessarily have the money to pay for the commercial value of the service they receive. Hence, for need to be transferred to demand, then the ability for the user to pay for the service becomes paramount. In this case, the people have to pay a subsidized fee to access the service. If this occurs, then the cost of investment will be greater than the revenue and this poses financial risk to the development of the infrastructure. Hence, universal service funding would have served as a revenue buffer to create a financial equilibrium that would sustain the project.

3. Network expansion: As mentioned earlier, both networks were small in size. They were not small due to the low population density of these areas, rather it was small due to the number of household connected. 
The Wireless Ghana project had about 20 households and institutions connected, while initially, the Dharamasala network was also small compared to the population of Dharamsala. Hence the existence of unconnected houses was the loss of potential economy for the NGOs. This is where Universal Service funding would also have played a role in facilitating.

However, as seen from the regulatory framework of both countries, both countries are committed towards facilitating rural Broadband connectivity. However, non of these countries provides regulatory frameworks and policies aimed at harnessing the development of bottom-up Broadband infrastructure development. This is not a policy debate yet in many developing countries, hence it difficult to identify the reasons why such policies either do not exist, will not exist or is not on the drawing board. But looking at the regulatory frameworks and structures, there is room to legally fund bottom-up initiatives. In India, where the possibility of demand pull exists, community networks should be allowed to bid for Universal Service fund subsidy. In most cases, they may be favored with the subsidy auctions. This could create competition and lead other carriers to become innovative in the delivery of their Broadband infrastructure and services to rural areas. In Ghana, there a supply push is necessary, the Universal Service funds has to identify means of sensitizing the rural dwellers about the usefulness of Broadband and the possibility in the people facilitating low-cost Broadband networks.

Aside, lessons, one would learn from the cases, one can also gain inspiration on the basic ingredient towards co-funding bottom-up approaches. If one were to look towards the some of the western countries to find out the core ingredient for the municipality and central government involvement in financing, bottom-up Broadband initiatives, one will identify political will. This can be seen in the case of Sweden, via municipality financing of the initiative and the United States where the FCC and the Public Utility Commissions (PUCs) in the states, team up to finance bottom-up initiatives. The only aspect of the US initiative, which may not be relevant to developing countries is having a threshold for refund that is too high.

Although these cases are examples of ambitious projects, bottom-up initiatives do not necessarily have to be ambitious. This is because there are rural areas in developing countries and in sub-Saharan Africa with smaller populations, who have access to some form of Broadband gateway. Connectivity from such small villages could be extended via point-to-point or 
point-to-multi-point connectivity to other small villages. In this manner, from a technical point of view, this is possible. If, or example, more villages in a clan are connected with a sizable subscriber strength, then paying for access to the Gateway, may necessarily be a problem. However, government regulation may be needed to protect the vulnerable community from the uncertainties of the market.

\section{Conclusion}

In this paper, an argument for the adoption of Universal Service funds to facilitate Broadband connectivity in rural areas of developing countries. The main focus are rural areas in India and Ghana. However, it can be extended to other developing countries. The argument was borne out of the fact that the attempt by people in rural areas to facilitate low-cost Broadband connectivity, identifies the willingness of the people to bear the cost of facilitating the service. However, bearing this cost is borne out of the usefulness of these services to the people. Two cases were studied in this paper. One in Africa and the other in Asia. In the African case, the service was delivered via a supply push and in the Asian case via a demand pull. This goes to prove the point that, somehow the service adoption will only occur after the usefulness of the service has been established by the people.

This co-financing idea as established on the fact that, some rural areas have access to Broadband Access connectivity and they have the organizational structures that will enable them mobilize themselves. These facts presented an opportunity for mobilizing and financing bottom up initiatives.

To further strengthen the argument for Universal Service funding, the case of the Wireless Ghana project and the Dharamsala wireless network were mentioned. In both countries, there was the opportunity to be funded via Universal Service funding. However, in the case of Dharamsala Wireless Network, they were not qualified for the subsidy auction. In the case of the Ghana Wireless project, they did not apply for funding. However, the former survived via private investor funding and the other was not sustainable due to lack of funding.

The fact that the people can co-finance the infrastructure, indicates that the universal service funding is only a buffer. And with Universal Service funding, small rural areas could be funded in batches over the years to attain Universal Access and Service. Although this possibility exists, it calls for more research into the feasibility of frameworks that would facilitate these initiatives. 


\section{References}

[1] Blackman, C., and Srivastava, L. (2011). Telecommunications Regulations Handbook: Tenth Anniversary Edition (Washington, DC: ITU/InfoDev/World Bank).

[2] BMWI. (2009). The Federal Government's Broadband Strategy. Retrieved from BMWI: https://www.bmwi.de/English/Redaktion/Pdf/ Broadband-strategy, property $=$ pdf, bereich $=$ bmwi, sprache $=e n, r w b=$ true . pdf [Accessed June 6, 2015].

[3] Broadband Commission. (2015). The state of Broadband 2015 (Geneva: ITU and UNESCO).

[4] Calandro, E., and Moyo, M. (2010). "Is the universal access fund in Africa creating an enabling environment for ict infrastructure investment in rural and perceived uneconomic areas?" in Proceedings 5th Communication Policy Research Conference (CPRsouth5), Xi'an, China, December 7, 2010 (Xi'an: SSRN).

[5] Census Info India. (2011). Houses, Household Amenities and Assets and Population data. Retrieved from Cencus India: http://www.devinfo. org/indiacensuspca/libraries/aspx/Home.aspx [Accessed September 26, 2014].

[6] DOT. (2004). The Gazette of India. Retrieved from Universal Service Obligatory Fund: http://www.usof.gov.in/usof-cms/GagendaPdf/Indian telegraphamendmentrules2004.pdf [Accessed May 6, 2015].

[7] Dowuona, S. (2015). Breaking News: MTN Wins 4G Spectrum Licence (Accra: Joy News).

[8] EC. (2014). 2014 Report on Implementation of the EU regulatory Framework for Electronic Communications. Retrieved from Digital for Europe: https://ec.europa.eu/digital-agenda/en/news/2014-report-imple mentation-eu-regulatory-framework-electronic-communications [Accessed June 6, 2015].

[9] Finquelievich, G., and Kisilevsky, G. (2005). Community democratization of telecommunications community cooperatives in Argentina: the case of TELPIN. J. Commun. Inform. 1, 27-40.

[10] Ghana Statistical Service. (2012). 2010 Population and Housing Census: Summary Report of Final Result (Accra: Ghana Statistical Service).

[11] GIFEC. (2012). The Common Telecommunications Facilities Project. Retrieved from GIFEC: http://gifec.gov.gh [Accessed April 7, 2013].

[12] GSMA. (2012). Universal Access How mobile can Bring Communication to all. Retrieved from GSMA: http://www.gsma.com/public 
policy/wp-content/uploads/2012/03/universalaccessexecutive.pdf [Accessed June 6, 2015].

[13] GSMA. (2013a). The Mobile Economy India 2013. Retrieved from GSMA: http://www.gsmamobileeconomyindia.com/GSMA_Mobile_Eco nomy_India_Report_2013.pdf [Accessed June 6, 2015].

[14] GSMA. (2013b). Survey of Universal Serivce Funds Key Findings (London: GSMA).

[15] Henry, H., and Constanze, S. (2011). Cooperatives for Peole-Centred Rural Development (Geneva: ILO).

[16] Hudson, H. (2014). "Digital Inclusion of Indigenous Populations: As Consumers And Privides Of Broadband Services," in PTC'14 New World, New Strategies, Honolulu, HI.

[17] ITU. (2013). Universal Service Fund And Digital Inclusion for All Study (Geneva: ITU).

[18] Jain, P., and Sridhar, V. (2003). Analysis of competition and market structure of basic telecommunication services in India. Commun. Strat. 52, 271-293.

[19] Jayakar, K. P., and Sawhney, H. (2004). Universal Service: beyond established practice to possibility space. Telecommun. Policy, 28, 339-357.

[20] Köthenbürger, M., Sinn, H., and Whalley, J. (2006). Privatization Experiences in the European Union (Cambridge, MA: MIT Press).

[21] Lindskog, H., and Johansson, M. (2005). Broadband: a municipal information platform: Swedish experience. Int. J. Technol. Manage. 31, 47-62.

[22] Noll, R., and Wallstein, S. (2005). "Universal Telecommunications Service in India," in The Second volume of the India Policy Forum, eds S. Bery, B. Bosworth, and A. Panagariya (Washington, DC: National Council of Applied Economic Research and the Brookings Institution), 254-287.

[23] Nungu, A., Brown, T., and Pehrson, B. (2011). "Challenges in sustaining municipal broadband networks in the developing world", in e-Technologies and Networks for Development, eds J. J. Yonazi, E. Sedoyeka, E. Ariwa, and E. El-Qawasmeh ( Heidelberg Dordrecht London New York: Springer), 363.

[24] OECD. (2012). Universal Service Policies in the context of National Broadband plans. Retrieved from OECD: http://www.oecd.org/officialdo cuments/publicdisplaydocumentpdf/?cote=DSTI/ICCP/CISP $\% 282011 \%$ 2910/FINAL\&docLanguage $=$ En [Accessed June 6, 2015]. 
[25] OFCOM. (2005). Review of Universal Service Obligation. Retrieved from OFCOM Office of communications: http://stakeholders.ofcom.org. $\mathrm{uk} /$ binaries/consultations/uso/statement/statementreview.pdf [Accessed June 6, 2015].

[26] Oost, E. V., Verhaegh, S., and Oudshoorn, N. (2007). From innovation community to community innovation: user-initiated innovation in wireless leiden. Sci. Technol Hum Values, 20.

[27] Salemink, K., and Bosworth, G. (2014). Investigating Community-Led Broadband Initiatives as a Model for Neo-Endogenous Development (New Zealand: Lincoln University).

[28] Shaffer, G. (2013). "Lessons learned from grassroots wireless networks in Europe," in Social and Economic Effects of Community Wireless Networks and Infrastructures, ed. A. Abdelaal (Hershey: IGI Global), 236-254.

[29] Siochrú, S. O., and Girard, B. (2005). Community-Based Networks And Innovative Technologies: New Models to Serve and Empower The Poor (New York: UNDP).

[30] Srivastava, V. (2012). Telecom Sector Financing in India: case study of Bombay Communications Limited (BCL)1. Int. Res. J. Appl. Fin. 2-12.

[31] Stern, P., and Townsend, D. (2006). New Models for Universal Access in Latin America. Regulatel/World Bank (PPIAF)/ECLAC Project on Universal Access of Telecommunications in Latin America.

[32] Strover, S., and Mun, S. (2006). Wireless Broadband, communities, and the shape of things to come. Govern. Inform. Q. 23, 348-358.

[33] Swati, and Pratrap, B. (2015). Telecom penetration in rural India: present scenario, future challenges and prospects. Asian J. Multidiscip. Stud. 3.

[34] Tapia, A., Maitland, C., and Stone, M. (2006). Making IT work for municipalities: building municipal wireless networks. Govern. Inform. $Q, 23,359-380$.

[35] Tesfamariam, K. (2015). Cooperative movement in ethiopia: development, challenges and proposed intervention. J. Econ. Sustain. Dev. 6.

[36] TRAI. (2000). TRAI ammendment Act 2000.

[37] TRAI. (2015). Highlights of Telecom Subscription Data as on 31 st March 2015 (New Delhi: Telecom Regulatory Authority of India).

[38] UK Universal Service Obligation. (2005). Universal Service Obligations $U K$. Retrieved from OFCOM: http://stakeholders.ofcom.org.uk/consultat ions/uso/main/ [Accessed June 06, 2015].

[39] Units under DOT. (2015). Units under DOT. Retrieved from Department of Telecommunications: http://www.dot.gov.in/content/units-under-dot [Accessed May 06, 2015]. 
[40] Universal Service Obligatory Fund (USOF). (2002). What is Universal Service. Retrieved from Universal Service Obligatory Fund: http://www. usof.gov.in/usof-cms/usof_home_contd.htm [Accessed May 06, 2015].

[41] Viardot, E. (2013). The role of cooperatives in overcoming the barriers to adoption of renewable energy. Energy Policy, 63, 756-763.

[42] Williams, I. (2015). Analysis of Public Privte Interplay Frameworks in the Development of Rural Telecommunications Infrastructure: A MultiCase Study (Aalborg: Aalborg University Press).

[43] Williams, I., and Kwofie, B. (2014). "The impact of liberalization on the mobile in Africa: the cases of Nigeria, Ghana, and Kenya," in The African Mobile Story, eds K. E. Skouby and I. Williams ( Aalborg: River Publishers), 17-40.

[44] Yardley, M. (2012). Developing successful Public-Private Partnerships to foster investment in universal Broadband networks. Retrieved from ITU: http://www.itu.int/ITU-D/treg/Events/Seminars/GSR/GSR12/docu ments/GSR12_BBReport_Yardley_PPP_7.pdf

\section{Biography}

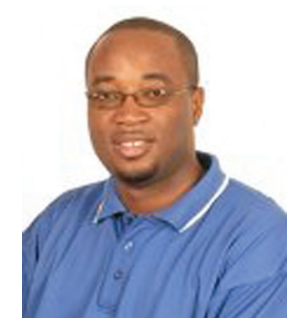

I. Williams is an Adjunct lecturer at Center for Communication, Media and Information Technologies (CMI) located at Aalborg University Copenhagen. He holds a Bachelor in Physics, a Master degree in Information and Communications Technologies and a Ph.D. He has since 2010 researched into socio-economic, socio-technical related to Information and Communications Technologies. His main research focus however is in the facilitation of telecom infrastructure using Public Private Partnerships.

He has authored more than 20 research publications, including journal papers, books, book chapters, conference papers and magazine articles. He is the co-editor of the Book, The African Mobile Story. He has organized conferences like the CMI annual conference and the CMI/GTUC conferences. 
